\section{Quality and Shelf Life of Snack Food as Influenced by Incorporation of High Protein Pulses in Multipurpose Flour}

\section{Saghir Ahmad*, Kaleem Ashraf and Irfan Khan}

Department of Post Harvest Engineering and Technology, Aligarh Muslim University, Aligarh, Uttar Pradesh, India

\begin{abstract}
The present study was conducted on development, quality evaluation of snack food prepared with multipurpose flour, namely wheat flour, gram flour, moong flour and urad flour, fried in refined and sunflower oil. The ultimate purpose of incorporation of urad flour and moong flour in the wheat and gram flour was to increase nutritional value of snack food. The urad and moong flour which are very rich in essential amino acid especially lysine, protein content and minerals was taken for incorporation as a substitute of highly priced protein food that will be obtained from animal sources. These flours also contain large amount of carbohydrates thus provide high energy. Eight snack food samples were prepared by the combination of different flour fried in different oil sources. The snack food prepared by the combination of wheat and gram flour has higher fat content. The urad flour and moong flour were incorporated in different proportion $(2.5 \%, 5 \%, 7.5 \%)$. The fat content of control samples was found between 26.82 to $33.11 \%$ (fried in mustard oil) and 23.30 to 30.71 (fried in sunflower oil) during 90 days of ambient storage. The $\mathrm{pH}$ value of snack food sample treated with $7.5 \%$ moong-urad flour(each) was found between 6.68 to 7.15 (fried in mustard oil) and 6.73 to 7.18 (fried in sunflower oil) at the end of 90 days of ambient storage. It has been noticed that the snack food samples fried in refined oil is of higher nutritional values than snack food samples fried in sunflower oil.
\end{abstract}

Keywords: Multipurpose Flour; Shelf life; Snack food; Quality

\section{Introduction}

A snack is a portion of food of ten times smaller than that of a regular meal that is generally eaten between meals. Snacks come in a variety of forms including packaged and processed foods and items made from fresh ingredients at home. The pear millet is comparable and even superior in some of the nutritional characteristics to major

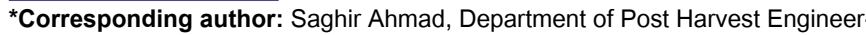
ing and Technology, Aligarh Muslim University, Aligarh, Uttar Pradesh, India, Tel: +919412601092, E-mail ; alsaghirqadri@gmail.com

Citation: Ahmad S, Ashraf K, Khan I (2017) Quality and Shelf Life of Snack Food as Influenced by Incorporation of High Protein Pulses in Multipurpose Flour. J Food Sci Nut 3: 019.

Received: October 05, 2016; Accepted: May 30, 2017; Published: June 21, 2017 cereals with respect to its energy value, protein, fat and minerals [1]. Plain snacks like plain cereals, pasta and vegetables are also mildly popular, and the word snack has often been used to refer to a larger meal involving cooked or leftover items. Six-meal eating is a form of eating that interjects healthy snacks in between small meals, to stave off hunger and promote weight loss. With growing concerns for diet, weight control and general health, government bodies like Health Canada are recommending that people make a conscious effort to eat more healthy, natural snacks- such as fruit, vegetables, nuts and cereal grains- while avoiding high-calorie, low-nutrient junk food. The growth of bakery industry is about $10 \%$ per annum and the products are increasingly becoming popular among all sections of people [2]. The use of millet flour is becoming more common in baked products especially in bread, cookies and crackers that are targeted at consumers who are gluten sensitive or diabetic [3]. The extruded ready to eat sweet and savory snacks developed using maize, green gram dhal and roasted bengal gram dhal in addition to enrichment with vitamin and iron [4]. Total fourteen commonly consumed traditional Indian bengal gram flour based snacks reported [5]. Deep fat frying is an important unit operation, which can be considered as the combination of frying and cooking. Several chemical and physical changes occur during the frying such as starch gelatinization, protein denaturation and crust formation. The amount of moisture in the deep-fried potatoes, evaporated was proportional to the square root of frying time. Snack food based on cereals and grains are low in nutrient density, high in calories and fat content and lack some essential amino acids like threonine, tryptophan and lysine [6]. Total eight varieties of traditional rice based snacks Pumaloi, Pudoh, Jashulia, Puthalo, Pukhlien, Pusaw, Pusla and Putyndong from Shillong and villages in the Ri-bhoi district [7]. Model systems for crust less and crust forming products, the amount of moisture evaporated was observed proportional to to the square root of frying time [8]. The variation in the moisture and oil contents of samples of $1.5 \mathrm{~mm}$ thick slices of $145^{\circ} \mathrm{C}, 165^{\circ} \mathrm{C} \& 185^{\circ} \mathrm{C}$ as a function of time and the moisture loss \& oil uptake were found to be interrelated [9]. The oil content in sev was recorded minimum when fried in cottonseed oil [10]. The market is estimated at US $\$ 3$ billion, with 50 percent comprising the organized snacks category. This category, growing at a healthy 30 percent annually, is sub-divided into the traditional segment (bhujia, chanachur), western segment (potato chips, cheese balls) and the newly established finger snacks segment, an adaptation of traditional offerings to the western format. The market in India is diverse and large with over 1,000 different snack products and some 300 types of savories. Potato-based snacks, and in particular potato chips, are the largest product segment, holding an 85 percent share of the salty snack market, followed by snack nuts, chickpeas and other pulse-based savory snacks. Organized retail chains have high demand for popcorn, diet snacks (soy nuts, bread sticks), breakfast cereals, baked and roasted snacks (biscuits, specialty breads, chocolate coated snacks, cookies etc.) and cheese snacks. Health foods, health food supplements and convenient foods are also rapidly growing segments. The Indian snacks market is worth around US\$ 3 billion, with the organized segment taking half the market share, and has an annual growth rate of 15-20 per cent. The unorganized snacks 
market is worth US\$ 1.56 billion, with a growth rate of 7-8 per cent per year. It should also be pointed out that the consumption of snack foods does not necessarily lead to health problems such as obesity, but the cause is rather an unbalanced diet with excess fat, sugar, and salt. In the light of above discussion, a study on the development of snack food was undertaken with the objectives of investigation as given below. It was to develop and study the quality \& stability of snack food with multipurpose flour incorporated with moong and urad flour.

\section{Materials and Methods}

\section{Methods of preparation of snack food}

The snack food samples fortified with moong flour and urad flour were prepared with different formulations as shown in table 1 . The urad and moong flour were incorporated in the snack food samples to increase the protein content of the snack food samples as shown in table 2. Multipurpose wheat and gram flour was taken in equal amount and the incorporation of the moong \& urad flour was done as tabulated below:

\begin{tabular}{|c|c|c|c|}
\hline Sample Code & Moong Flour \% & Urad Flour \% & $\begin{array}{c}\text { MPF (Wheat Flour: Gram } \\
\text { Flour }\end{array}$ \\
\hline S1 & 0 & 0 & $1: 1$ \\
\hline S2 & 2.5 & 2.5 & $1: 1$ \\
\hline S3 & 5 & 5 & $1: 1$ \\
\hline S4 & 7.5 & 7.5 & $1: 1$ \\
\hline M1 & 0 & 0 & $1: 1$ \\
\hline M2 & 2.5 & 2.5 & $1: 1$ \\
\hline M3 & 5 & 5 & $1: 1$ \\
\hline M4 & 7.5 & 7.5 & $1: 1$ \\
\hline
\end{tabular}

Table 1: The formulations of snack food samples.

\begin{tabular}{|c|c|c|}
\hline $\begin{array}{c}\text { Sample } \\
\text { Code }\end{array}$ & $\begin{array}{c}\text { Protein Content in the Formulations } \\
\text { (In Grams per 500 g of Sample) }\end{array}$ & $\begin{array}{c}\text { Protein Content in } \\
\text { the Formulations (\%) }\end{array}$ \\
\hline S1 & 88.47 & 17.694 \\
\hline S2 & 89.92 & 17.98 \\
\hline S3 & 91.60 & 18.32 \\
\hline S4 & 93.15 & 18.63 \\
\hline M1 & 88.47 & 17.694 \\
\hline M2 & 89.92 & 17.98 \\
\hline M3 & 91.60 & 18.32 \\
\hline M4 & 93.15 & 18.63 \\
\hline \multicolumn{2}{|c|}{ Table 2: The protein content of samples formulations. } \\
\hline
\end{tabular}

The process flow chart has method of preparation (Flow Chart 1).

\section{Physicochemical properties}

The physicochemical properties of snack food samples were evaluated based on the methods described by the Association of Official Analytical Chemist (AOAC).

\section{Moisture content}

The moisture content is an important factor to analyse the quality and shelf life of snack food products as the moisture is the critical entity to support the microbial growth \& proliferation. The moisture content was evaluated as per the AOAC guidelines. Initially, the weight of individual petridishes taken separately then took 10 grams of each snack food sample in different flat bottom dried petridishes.

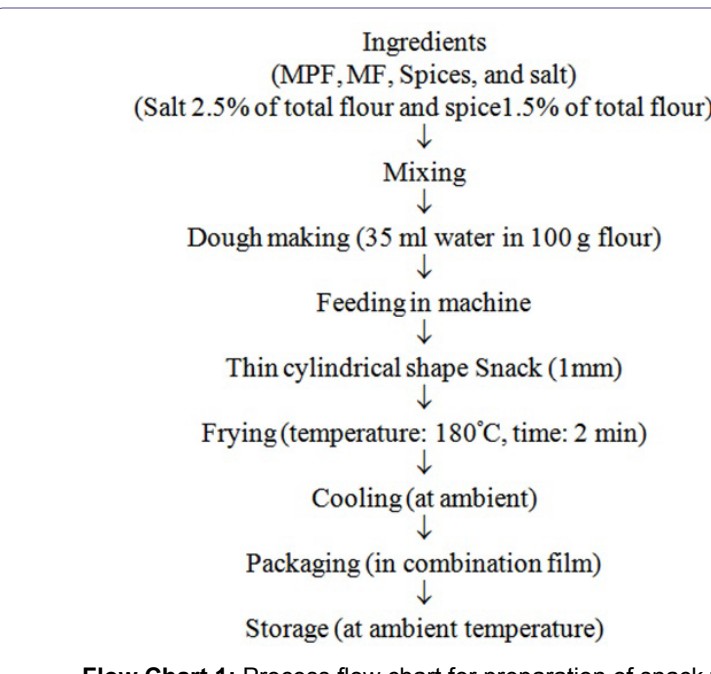

Flow Chart 1: Process flow chart for preparation of snack food.

The samples then placed in hot air oven (Yorco Hot Air Sterilizer, India) maintained at $100 \pm 5^{\circ} \mathrm{C}$ temperature upto four hours. At the end, the samples was removed from the oven and placed in desiccator and after getting cool, the samples weighed again to calculate the moisture content in the samples. The snack food samples stored at ambient temperature were monitored for ninety days to evaluate the effect on moisture content and it was reported to increase continuously till the $90^{\text {th }}$ day of storage period as shown in the figure 1.

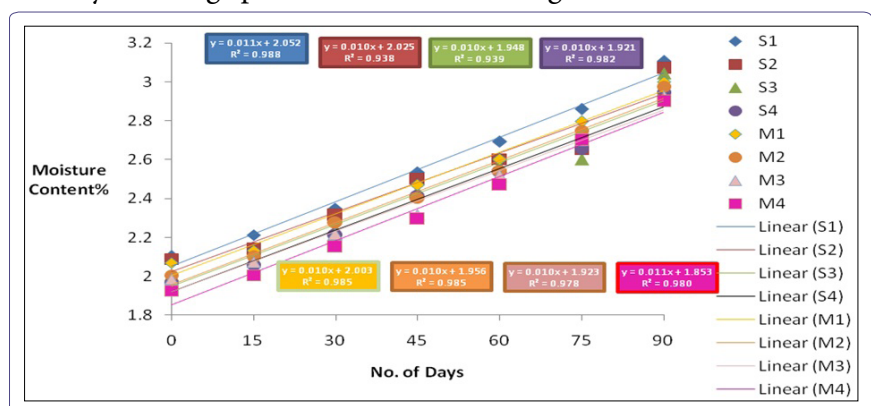

Figure 1: Evaluation of moisture content of snack food samples (control and incorporated with different levels of moong-urad flour) during ambient storage.

\section{Fat content}

The petroleum ether extracts the crude fat of snack food which represents the true fat (Tryglyceride) and other lipids such as phospholipids, sterols, essential oils and fat soluble pigments. Fat was extracted with soxhlet apparatus by method as described by AOAC method. $2 \mathrm{~g}$ of each snack food sample $(\mathrm{W})$ was taken into thimble and weighed with thimble $\left(\mathrm{W}_{1}\right)$. Thimble was inserted in the thimble holder. In soxhlet apparatus the sample was kept in a thimble and it was extracted with petroleum ether which was kept in the round bottom flask. The temperature and time for extraction were adjusted to $100^{\circ} \mathrm{C}$ and $45 \mathrm{~min}$ respectively. After $45 \mathrm{~min}$ of extraction, the recovery was carried out for $45 \mathrm{~min}$ at $140^{\circ} \mathrm{C}$. After the completion of reclamation, all the unrecovered solvent was evaporated by putting into oven at $100^{\circ} \mathrm{C}$ for $15-30 \mathrm{~min}$. The beaker containing fat was weighed $\left(\mathrm{W}_{2}\right)$. The fat content was found to decrease during the storage period of snack food till the 90 days as shown in figure 2 .

\section{pH value}

$10 \mathrm{~g}$ of each snack food sample was taken and homogenized with $50 \mathrm{ml}$ distilled water. The ground sample was filtered and the $\mathrm{pH}$ was 


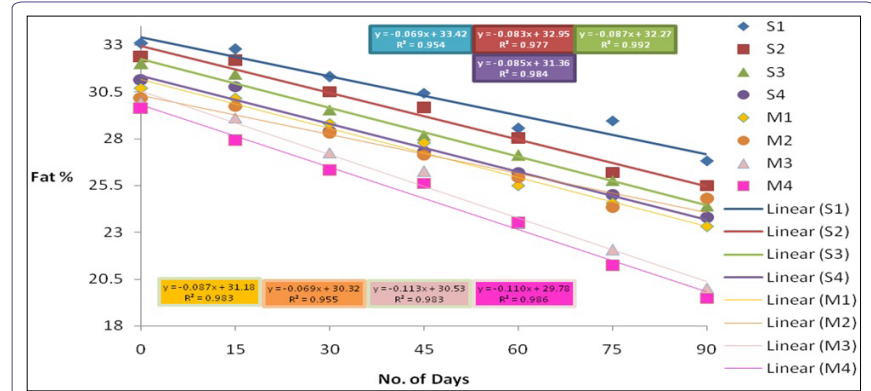

Figure 2: Evaluation of fat content of snack food samples (control and incorporated with different levels of moong-urad flour) during ambient storage.

measured with the combined glass electrode of a digital $\mathrm{pH}$ meter (Khera model, Indian make). The $\mathrm{pH}$ value was found to decrease due to oxidation of fat content which leads to the formation of fatty acids in the sample. The trend of $\mathrm{pH}$ value is shown in the figure 3 that shows the decreasing behavior of the snack food sample.

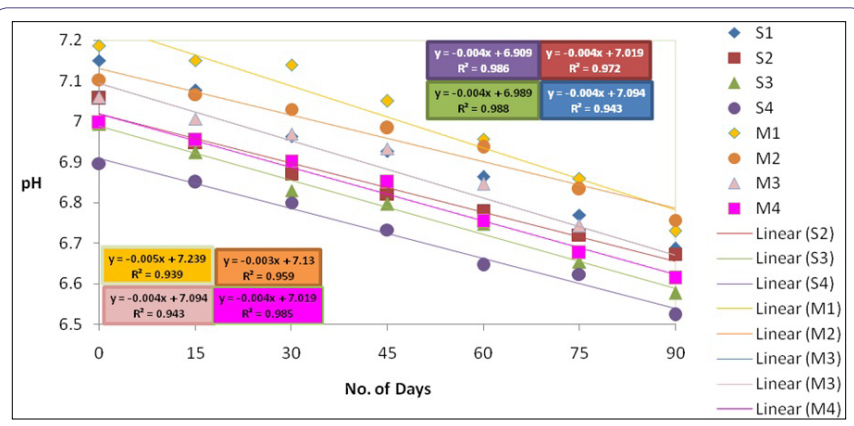

Figure 3: Evaluation of $\mathrm{pH}$ value of snack food samples (control and incorporated with different levels of moong-urad flour) during ambient storage.

\section{Ash content}

The ash content is basically the measure of mineral matter of the food sample. It was measured as per the Association of Official Analytical Chemist (AOAC) method. dried samples obtained after the determination of moisture content was weighed in crucible of known weight and ignited at $550^{\circ} \mathrm{C}$ for $6 \mathrm{hrs}$ in the muffle furnace (Model: Tanco). It was then taken out, allowed to cool for a moment, and then placed in desiccator until cooled and finally weighed to a constant weight. The ash content is decreasing relatively due to increase in the moisture content continuously during the storage period of 90 days as shown in the figure 4 .

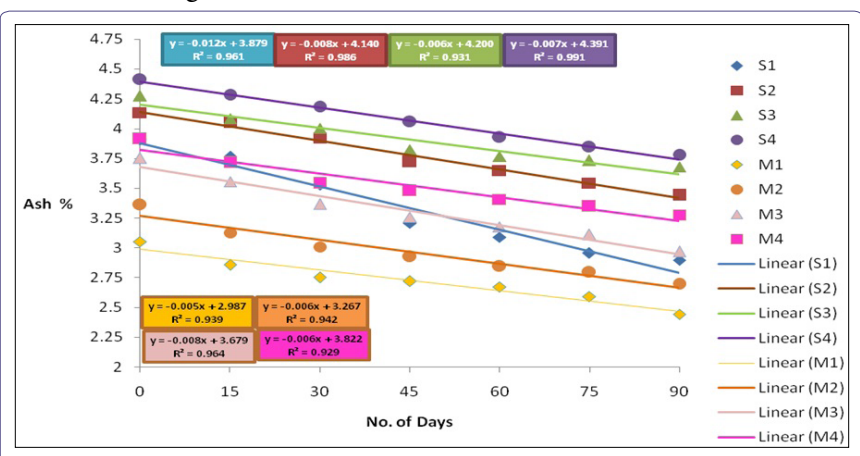

Figure 4: Evaluation of ash content of snack food samples (control and incorporated with different levels of moong-urad flour) during ambient storage.

\section{Free fatty acids}

Free fatty acids are the percentage by weight of specified fatty acids (e.g., percent oleic acid). It is the measure of fatty acidity that normally reflects the amount of fatty acids hydrolyzed from triacylglycerols. In addition to free fatty acids, acid phosphates and amino acids can also contribute to acidity. In samples containing no acids other than fatty acids, acid value and FFA may be converted from one to the other using a conversion factor. Acid value is defined as the mg of $\mathrm{KOH}$ necessary to neutralize the free acids present in $1 \mathrm{gm}$ of factor oil. Sometimes acidity of edible oils and fats is expressed as $\mathrm{ml}, \mathrm{N} \mathrm{NaOH}$ required to neutralize the fatty acids in $100 \mathrm{~g}$ fat or oil. Free fatty acids are the results of fat oxidation which found to increase during the storage period of 90 days as shown in the figure 5 .

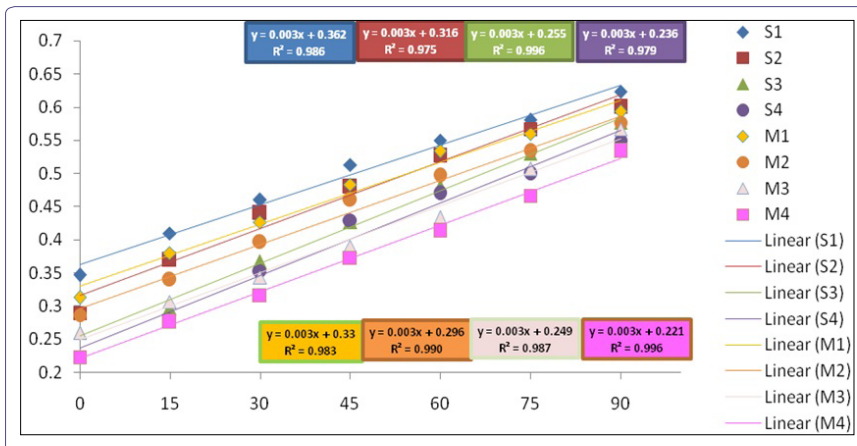

Figure 5: Evaluation of free fatty acids of snack food samples (control and incorporated with different levels of moong-urad flour) during ambient storage.

\section{Thiobarbituric acid test}

This is one of the most widely used tests for evaluating the extent of lipid oxidation. Oxidation products of unsaturated systems produce a colour reaction with Thiobarbituric Acid (TBA). It is believed that the chromagen results from condensation of two molecule of TBA with one molecule of malonaldehyde. However, malonaldehyde is not always present in all oxidized system. Many alkanals, alkenals, and 2, 4-dienals produce a yellow pigment $(450 \mathrm{~nm})$ in conjugation with TBA, but only dienals produce a red pigment (at $530 \mathrm{~nm}$ ). It has been suggested that measurement at both absorption maxima is desirable. In general, TBA-reactive material is produced in significant amounts only from fatty acids containing three or more double bonds. The trends of TBA behavior are shown in the figure 6 .

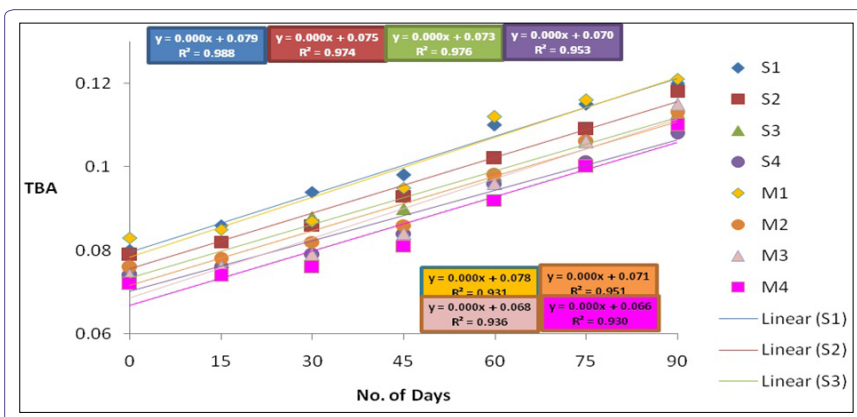

Figure 6: Evaluation of TBA value of snack food samples (control and incorporated with different levels of moong-urad flour) during ambient storage.

\section{Peroxide value}

The peroxide value is basically defined as the amount of peroxide oxygen generated per 1 kilogram of fat or oil. It is measurement to know the degree of oxidation that has been occurred or simply the extent of rancidity reactions in food samples. It is expressed in terms of milliequivalents or millimoles per kilograms. Peroxides are the intermediate compounds synthesized during autoxidation reaction. Autoxidation is a free radical reaction involving oxygen that leads 
to deterioration of fats and oils, which is responsible for off-flavours and off-odours. The Peroxide value in case of fresh oils is always < 10 milliequivalents $/ \mathrm{kg}$. The peroxide value lies in the range of $30-40$ milliequivalents $/ \mathrm{kg}$ in case of rancidity. The peroxide value was found to increase during storage period because of fat oxidation as shown in the figure 7 .

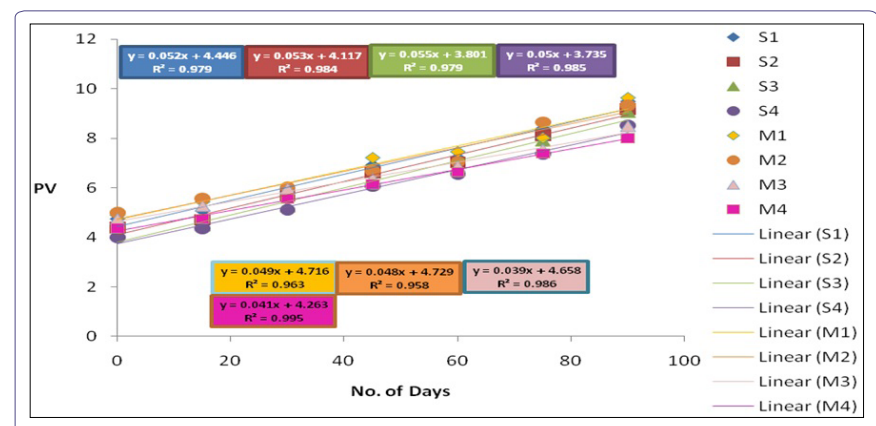

Figure 7: Evaluation of Peroxide value of snack food samples (control and incorporated with different levels of moong-urad flour) during ambient storage.

\section{Statistical analysis}

\section{Standard deviation}

The best and most commonly used statistical evaluation of the precision of analytical data is standard deviation. The standard deviation measures the spread of the experimental values and given a good indication of how close the values exist to each other. The Samples were prepared in three replication and data obtained for selected quality parameters were analyzed for mean and standard deviations using following formula:

$\mathrm{SD}= \pm \sqrt{\sum(X I-X)^{2 / n}}$

Where $\mathrm{Xi}=$ Individual

$\mathrm{X}=$ Mean of individual

$\mathrm{n}=$ Total population of sample

\section{Analysis of variance}

To test the significance of the effect of treatment and storage period on quality parameters, analysis of variance (ANOVA) of the collected data for different properties was carried out as applicable to experiments of randomized design [11]. The Least Significant Differences (LSD) or Critical Differences (CD) of mean values were calculated using formula:

$\mathrm{LSD}=\sqrt{\frac{2 \times(S)^{2}}{n} \times t}$

Where,

$S=$ Error of total sum of deviation squares

$\mathrm{n}=$ No. of replications

$\mathrm{t}=$ Value at 0.05 obtained at the degree of freedom

\section{Results \& Discussion}

The results of physicochemical properties of fresh snack food samples have been given in table 3. The fresh snack food samples $M_{1}, M_{2}$, $M_{3}, M_{4}, S_{1}, S_{2}, S_{3}$, and $S_{4}$ prepared from multipurpose flour and different proportion of moong and urad flour has the moisture content $2.10 \%$, $2.09 \%, 2.00 \%, 1.97 \%, 2.07 \%, 2.00 \%, 1.98 \%$ and $1.92 \%$ respectively as shown in the figure 1 . The sample $\mathrm{S}_{4}$ prepared with $7.5 \%$ moong and urad flour fried in sunflower oil had lowest moisture content (1.92\%) of all the remaining snack food samples based on only Multipurpose Flour (MPF) and multipurpose flour incorporated with $2.5 \%, 5 \%$ and $7.5 \%$ each of moong and urad flour fried in mustard oil and sunflower oil. Treatment of moong-urad flour significantly $(\mathrm{p}<0.05)$ decreased moisture content of snack food samples. Similar results men also obtained by Labuza and Schimidt (1985) who suggested that moisture absorption might be due to storage condition and air available inside packaging material. Initially fat contents of all snack food samples were found in the range of 29.51 to $33.05 \%$ (Table 3). The fat content of snack food sample $S_{1}$ was found to be $33.05 \%$, which was higher as compared to remaining snack food samples prepared from combination of multipurpose flour incorporated with different levels of moong-urad flour namely $\mathrm{S}_{2}, \mathrm{~S}_{3}, \mathrm{~S}_{4}, \mathrm{M}_{1}, \mathrm{M}_{2}, \mathrm{M}_{3}$ and $\mathrm{M}_{4}$ (The samples $\mathrm{S}_{2}, \mathrm{~S}_{3}, \mathrm{~S}_{4}, \mathrm{M}_{1}, \mathrm{M}_{2}, \mathrm{M}_{3}$ and $\mathrm{M}_{4}$ had $32.34 \%, 31.91 \%, 31.01 \%, 30.71 \%$, $30.28 \%, 30.01 \% \& 29.51 \%$ fat content respectively as shown in the figure 2).Treatment of moong-urad flour significantly $(\mathrm{p}<0.05)$ decreased fat content of snack food samples. The $\mathrm{pH}$ values, of eight different fresh samples of snack food were found between 7.01 to 7.18. The $\mathrm{pH}$ value of snack food sample $\left(\mathrm{M}_{1}\right)$ was 7.18 , which was higher as compared to remaining snack food samples $S_{1}, S_{2}, S_{3}, S_{4}, M_{2}, M_{3}$ and $M_{4}$ prepared from MPF incorporated with different levels of moong-urad flour. The $\mathrm{pH}$ values of snack food samples $\mathrm{S}_{1}, \mathrm{~S}_{2}, \mathrm{~S}_{3}, \mathrm{~S}_{4}, \mathrm{M}_{2}, \mathrm{M}_{3}$ and $\mathrm{M}_{4}$ were found to be 7.14, 7.04, 6.98, 6.90, 7.09, 7.06 and 7.01 respectively as shown in the figure 3 . As incorporation of moong-urad flour, $\mathrm{pH}$ value decreased because $\mathrm{pH}$ of moong-urad flour was found less than $\mathrm{pH}$ of MPF. Therefore treatment of moong-urad flour significantly $(\mathrm{p}<0.05)$ decreased the $\mathrm{pH}$ of the snack food samples. Ash contents, of eight different samples of snack food were found between 3.04 to $4.40 \%$. The ash content of snack food samples $\mathrm{S}_{4}$ was $4.40 \%$, which was higher as compared to remaining snack food samples $S_{1}, S_{2}, S_{3}, M_{1}, M_{2}$, $\mathrm{M}_{3}$ and $\mathrm{M}_{4}$ prepared from multipurpose flour incorporated with different levels of moong-urad flour. The ash contents of snack food samples $S_{1}, S_{2}, S_{3}, M_{1}, M_{2}, M_{3}$ and $M_{4}$ were found to be $3.91 \%, 4.13 \%, 4.24 \%$, $3.04 \%, 3.35 \%, 3.75 \%$ and $3.89 \%$ respectively as shown in the figure 4 . Treatment of moong-urad flour significantly $(\mathrm{p}<0.05)$ increased the ash content of snack food sample. The FFA contents of snack food samples were found between 0.24 to $0.35 \%$ oleic acids. The FFA contents of snack food sample $S_{1}$ was found $0.35 \%$ of oleic acids. It was higher as compared to remaining snack food samples prepared from multipurpose flour incorporated with different levels of moong-urad flour. The FFA content of snack food samples $S_{2}, S_{3}, S_{4}, M_{1}, M_{2}, M_{3}$ and $\mathrm{M}_{4}$ treated with moong-urad flour were found $0.30 \%, 0.26 \%, 0.24 \%$, $0.31 \%, 0.29 \%, 0.26 \%$ and $0.0 .24 \%$ of oleic acid respectively as shown in the figure 5. As moong-urad flour has low fat content and moisture content, which helped in preventing oxidation of fat into fatty acids. It was due to antioxidant property of moong flour. Therefore, treatment of moong flour significantly $(\mathrm{p}<0.05)$ decreased FFA of snack food samples. The peroxide values of eight different snack food samples were found between 4.36 to 6.73 meq $\mathrm{O}_{2}$ per $\mathrm{kg}$ fat, which was found under safe limit. The peroxide value of snack food samples $\mathrm{S}_{1}$ was 6.73 meq $\mathrm{O}_{2}$ per kg, which was higher as compared to other snack food samples $S_{2}, S_{3}, S_{4}, M_{1}, M_{2}, M_{3}$ and $M_{4}$ treated with moong-urad flour (The PV of snack food samples $\mathrm{S}_{2}, \mathrm{~S}_{3}, \mathrm{~S}_{4}, \mathrm{M}_{1}, \mathrm{M}_{2}, \mathrm{M}_{3}$ and $\mathrm{M}_{4}$ were found $6.39,6.16,5.99,5.23,4.99,4.73$ and 4.36 meq $_{2}$ per kg respectively as shown in the figure 7). This was due to antioxidant property of moong flour. Therefore, treatment of moong flour significantly $(\mathrm{p}<0.05)$ decreased PV of snack food samples. The TBA numbers of snack food samples in fresh condition were found between 0.072 to $0.080 \mathrm{mg} / \mathrm{kg}$ 
Citation: Ahmad S, Ashraf K, Khan I (2017) Quality and Shelf Life of Snack Food as Influenced by Incorporation of High Protein Pulses in Multipurpose Flour. J Food Sci Nut 3: 019.

- Page 5 of $5 \cdot$

\begin{tabular}{|c|c|c|c|c|c|c|c|c|}
\hline \multirow{2}{*}{ Constituent } & \multicolumn{9}{|c|}{ Sample code } \\
\cline { 2 - 8 } & $\mathbf{S}_{1}$ & $\mathbf{S}_{2}$ & $\mathbf{S}_{3}$ & $\mathbf{S}_{4}$ & $\mathbf{M}_{1}$ & $\mathbf{M}_{2}$ & $\mathbf{M}_{3}$ & $\mathbf{M}_{4}$ \\
\hline Moisture content, $\%$ & $2.10 \pm 0.01$ & $2.09 \pm 0.01$ & $2.00 \pm 0.01$ & $1.97 \pm 0.02$ & $2.07 \pm 0.02$ & $2.00 \pm 0.01$ & $1.98 \pm 0.02$ & $1.92 \pm 0.02$ \\
\hline Fat content, \% & $33.11 \pm 0.06$ & $32.36 \pm 0.98$ & $32.01 \pm 0.09$ & $31.13 \pm 0.10$ & $30.71 \pm 0.20$ & $30.15 \pm 0.11$ & $29.90 \pm 0.10$ & $29.60 \pm 0.09$ \\
\hline pH value & $7.15 \pm 0.01$ & $7.05 \pm 0.01$ & $6.99 \pm 0.01$ & $6.89 \pm 0.02$ & $7.18 \pm 0.01$ & $7.10 \pm 0.01$ & $6.99 \pm 0.02$ & $7.07 \pm 0.02$ \\
\hline Ash content, \% & $3.90 \pm 0.05$ & $4.13 \pm 0.01$ & $4.27 \pm 0.03$ & $4.41 \pm 0.03$ & $3.05 \pm 0.05$ & $3.36 \pm 0.02$ & $3.75 \pm 0.05$ & $3.91 \pm 0.03$ \\
\hline FFA, \% & $0.34 \pm 0.02$ & $0.29 \pm 0.03$ & $0.26 \pm 0.03$ & $0.22 \pm 0.03$ & $0.31 \pm 0.02$ & $0.28 \pm 0.03$ & $0.26 \pm 0.02$ & $0.22 \pm 0.01$ \\
\hline PV meq O $/ \mathrm{kg}$ & $4.73 \pm 0.01$ & $4.39 \pm 0.01$ & $4.16 \pm 0.01$ & $3.99 \pm 0.02$ & $4.89 \pm 0.01$ & $4.99 \pm 0.01$ & $4.73 \pm 0.01$ & $4.36 \pm 0.02$ \\
\hline TBA number & $0.080 \pm 0.06$ & $0.079 \pm 0.02$ & $0.076 \pm 0.01$ & $0.074 \pm 0.01$ & $0.087 \pm 0.01$ & $0.088 \pm 0.01$ & $0.086 \pm 0.01$ & $0.081 \pm 0.01$ \\
\hline
\end{tabular}

Table 3: Physicochemical properties and microbial characteristics of snack food prepared from MPF and Moong-Urad flour (in fresh condition).

of malonaldehyde. The TBA value for snack food sample $\mathrm{S}_{1}$ was found to be $0.080 \mathrm{mg} / \mathrm{kg}$ of malonaldehyde, which was more than TBA value of snack food samples $S_{2}, S_{3}, S_{4}, M_{1}, M_{2}, M_{3}$ and $M_{4}$ prepared from combination of multipurpose flour incorporated with different levels of moong-urad flour (The TBA number of snack food samples were $0.079,0.076,0.074,0.73$ and $0.72 \mathrm{mg} / \mathrm{kg}$ of malonaldehyde respectively as shown in the figure 6). Treatment of moong flour significantly $(\mathrm{p}<0.05)$ decreased TBA number of snack food samples.

\section{Conclusion}

The snack food samples of high nutrient density were prepared from multipurpose flour incorporated with different levels of moong flour and urad flour. The composition and nutritive value of snack food samples based on wheat flour, gram flour, urad and moong flour represented balanced quantity of carbohydrate, protein, minerals, fat, dietary fiber, and these samples were acceptable in sensory evaluation. Since the moong and urad flour has high level of protein, minerals and phenolic compounds, which acts as strong antioxidant. The peroxide value, FFA and TBA number were found to be in safe range and there were no sign of deterioration in snack food samples after 90 days of ambient storage. These snack food samples could be of great help in improving the health of snack food consumers by serving as good supplements and provide a new way of consumption of such legumes, which cannot be consumed directly but has high nutritive value.

\section{Acknowledgement}

Authors are thankfully acknowledges the Department of Post Harvest Engineering \& Technology, Aligarh Muslim University, Aligarh city of Uttar Pradesh (India) for extending the research facilities to complete the experimental work related to the objective of the investigation.

\section{References}

1. Abdalla AA, Tinay AHE, Mohamed BE, Abdalla AH (1998) Proximate composition, starch and mineral contents of 10 pearl millet genotypes. Food Chem 63: 243-246.

2. Indrani S, Savithri GD, Venkateswara RG (1997) Effect of defatted soy flour on the quality of buns. J Food Sci Technol 34: 440-442.

3. Lovis LJ (2003) Alternatives to wheat flour in baked goods. Cereal Food World 48: 61-63.

4. Devi L, Khader V, Rao M (2005) Development and acceptability of ready to eat snack for the institutionalized elderly. J Food Sci Technol 42: 176-179.

5. Ankleshwarla NT, Karkar PD (2001) Studies on sodium and potassium content of traditional bengal gram flour based snacks. Indian Food Packer 137.

6. Jean IJ, Work R, Camire ME, Briggs J, Barrett AH et al. (1996) Selected properties of extruded potato and chicken meat. J Food Sci Technol 61: 783-789.

7. Agrahar MD, Subbulakshmi G (2005) Nutritional evaluation and processing methods of some traditional snacks consumed by the khasi tribals of Meghalaya. J Food Sci Technol 42: 255-258.

8. Mittelman AN, Mizrahi S, Brek Z (1984) Heat and mass transfer in frying: In: Mckenna BD (ed.). Engineering and Food: Engineering sciences in the food industry. Elseveir Applied Science Publication, Amsterdam, Netherlands.

9. Gamble MH, Rice P, Selman JD (1987) Relationship between oil uptake and moisture loss during frying of potato slice from c.v record U.K tubers. Int $\mathrm{J}$ Food Sci Technol 22: 233-241.

10. Annapure US, Singhal RS, Kulkarni PR (1998) Studies on deep-fat fried snacks from some cereals and legumes. Journal of the Science of Food and Agriculture 76: 377-382

11. Mandal, RC, Nambian PTN (1999) Analysis of covariance in agricultural statistics techniques and procedures. Agro Botanical Publishing, Bikaner, India. Pg no: 135-139. 